\title{
PENGARUH INTENSITAS PEMOTONGAN TERHADAP PRODUKTIVITAS Indigofera zollingeriana
}

\author{
Ivan H. G. M. Wagiu, Ch. L. Kaunang, M.M. Telleng, W.B. Kaunang
}

Fakultas Peternakan Universitas Sam Ratulangi, Manado 95115

\begin{abstract}
ABSTRAK
Penelitian ini bertujuan untuk mengetahui pengaruh intensitas pemotongan terhadap produksi segar daun dan batang, produksi berat kering daun dan batang, serta rasio daun/batang Indigofera zollingeriana. Penelitian ini menggunakan Rancangan Acak Lengkap (RAL) dengan 4 perlakuan dan 5 ulangan. Perlakuan intensitas yang diberikan yaitu: 1) $\mathrm{I}_{1}$ (intensitas $75 \mathrm{~cm}$ ), 2) $\mathrm{I}_{2}$ (intensitas $100 \mathrm{~cm}$ ), 3) $\mathrm{I}_{3}$ (intensitas $125 \mathrm{~cm}$ ), dan 4) $\mathrm{I}_{4}$ (intensitas $150 \mathrm{~cm}$ ). Hasil analisis menunjukkan bahwa intensitas pemotongan berpengaruh sangat nyata $(\mathrm{P}<0,01)$ terhadap produksi segar batang dan daun, produksi berat kering batang dan daun, serta rasio daun-batang Indigofera zollingeriana. Produksi batang segar dan kering Indigofera zollingeriana pada intensitas $75 \mathrm{~cm}$ sangat nyata $(\mathrm{P}<0,01)$ lebih tinggi dari intensitas $100 \mathrm{~cm}, 125 \mathrm{~cm}$, dan $150 \mathrm{~cm}$. Produksi daun segar dan kering Indigofera zollingeriana pada intensitas $75 \mathrm{~cm}$ sangat nyata $(\mathrm{P}<0,01)$ lebih tinggi dari umur pemotongan $125 \mathrm{~cm}$ dan $150 \mathrm{~cm}$. Rasio daun/batang Indigofera zollingeriana pada intensitas $125 \mathrm{~cm}$ sangat nyata $(\mathrm{P}<0,01)$ lebih tinggi dari umur pemotongan $75 \mathrm{~cm}, 100 \mathrm{~cm}$ dan $150 \mathrm{~cm}$. Disimpulkan bahwa produktivitas indigofera tertinggi yaitu pada intensitas $125 \mathrm{~cm}$.
\end{abstract}

Kata kunci: Indigofera zollingeriana, intensitas pemotongan, produktivitas.

*Korespondensi (corresponding author):

Email: charleskaunang@unsrat.ac.id
ABSTRACT

\begin{tabular}{ccr}
\multicolumn{1}{c}{ THE } & EFFECT & OF \\
DEFOLIATION & INTENSITY & ON \\
PRODUCTIVITY & OF & Indigofera
\end{tabular}
zollingeriana. This research aims to know the effect of defoliaion intensity on productivity (fresh production, dry weight production, proportion of leaves and stems) and to know the defoliation intensity with optimal productivity of forage Indigofera zollingeriana. This research was conducted in December 2019 until March 2020. It consisted of defoliation intensity at $75 \mathrm{~cm}$ (T75), $100 \mathrm{~cm}$ (T100), $125 \mathrm{~cm}$ (T125), and $150 \mathrm{~cm}(\mathrm{~T} 150)$. The design used in this experiment is Completely Randomized Design. The variables in this research were 1. fresh production leaves and stems; 2 . dry weight production leaves and stems; 3 . the proportion of leaves and stems dry weight production of forages Indigofera zollingeriana. The results showed that the difference of intensity defoliation had a significantly effect $(\mathrm{P}<0,01) \quad$ on productivity (fresh production, dry weight production, proportion of leaves and stems) forage Indigofera zollingeriana. Defoliation intensity $75 \mathrm{~cm}$ have significantly $(\mathrm{P}<0,01)$ fresh and dry weight leaf of Indigofera zollingeriana than hight defoliation $125 \mathrm{~cm}$ and $150 \mathrm{~cm}$. Intensity defoliation $125 \mathrm{~cm}$ have significantly $(\mathrm{P}<0,01)$ leaf-stem ratio of Indigofera zollingeriana than any other. It conclude that intensity defoliation $125 \mathrm{~cm}$ have highly productivity.

Keywords: Indigofera zollingeriana, cutting intensity, productivity. 


\section{PENDAHULUAN}

Produktivitas peternakan di Indonesia masih rendah karena mutu hijauan pakan ternak terutama pada musim kemarau sangat rendah sehingga ketersediaan pakan untuk ternak ruminansia khususnya hijauan merupakan masalah yang masih sulit di Indonesia. Rendahnya kualitas pakan ditandai dengan tingginya kandungan serat kasar sehingga zat-zat makanan esensial seperti protein, energi dan mineral menjadi kurang tersedia untuk kebutuhan ternak. Penyediaan hijauan pakan yang berkualitas mutlak diperlukan dalam rangka meningkatkan produksi dan produktivitas ternak ruminansia (Telleng et al., 2016).

Jenis hijauan yang dapat diberikan untuk ternak selain rumput-rumputan yaitu tanaman leguminosa yang mempunyai kandungan protein cukup tinggi dibandingkan dengan jenis rumputrumputan. Leguminosa merupakan salah satu jenis tumbuhan dikotil yang mempunyai kemampuan mengikat (fiksasi) nitrogen langsung dari udara (tidak melalui cairan tanah) karena bersimbiosis dengan bakteri tertentu pada akar atau batangnya (Tillman et al.,1998). Hijauan pakan jenis leguminosa memiliki sifat yang berbeda dengan rumput-rumputan, jenis legum umumnya kaya akan protein, kalsium, dan fosfor (Tillman, et al., 1998).
Tanaman leguminosa pohon telah dikenal memiliki potensi sebagai sumber pakan berkualitas tinggi, terutama selama musim kering saat ketersediaan hijauan rumput menurun tajam, salah satu jenis tanaman leguminosa pohon yang dapat dipakai sebagai pakan ternak adalah Indigofera zollingeriana. Karakteristik dari tanaman leguminosa Indigofera adalah kandungan protein dan biomasanya tinggi, toleran terhadap musim kering, genangan air dan tanah yang memiliki salinitas tinggi, sehingga Indigofera sangat baik untuk dikembangkan sebagai hijauan pakan ternak untuk daerah yang memiliki potensi cekaman biotik dan abiotik tinggi (Hassen et al., 2007). Tanaman ini memiliki kandungan protein kasar yang tinggi dan kandungan mineral yang tinggi ideal bagi ternak perah, struktur serat yang baik dan nilai kecernaan yang tinggi bagi ternak ruminansia (Abdullah dan Suharlina, 2010).

Indigofera zollingeriana merupakan tanaman pakan ternak dari kelompok leguminosa pohon. Saat ini Indigofera zollingeriana telah dimanfaatkan sebagai bahan pakan ternak ruminansia. Leguminosa pohon ini memiliki produktivitas yang tinggi dan kandungan nutrisi yang cukup baik, terutama kandungan proteinnya yang tinggi. Tanaman ini dapat dimanfaatkan sebagai pakan ternak yang kaya akan nitrogen, 
fosfor, kalium, dan kalsium. Akbarillah dan Kaharuddin, 2002) melaporkan nilai nutrisi tepung daun Indigofera Zollingeriana adalah: protein kasar $27,97 \%$, serat kasar 15,25\%, $\mathrm{Ca} 0,22 \%$, dan $\mathrm{P} 0,18 \%$. Selanjutnya disebutkan bahwa sebagai sumber protein, tepung daun Indigofera zollingeriana mengandung pigmen yang cukup tinggi seperti xantofil dan carotenoid.

Pemotongan tanaman pakan yang tepat merupakan faktor penting, terutama pada faktor umur pemotongan karena hal tersebut akan menentukan produksi sekaligus juga kandungan nutrisinya. Semakin bertambahnya usia tanaman, maka akan mengakibatkan perbandingan persentase daun dengan batang semakin kecil. Kecilnya rasio daun dengan batang berpengaruh terhadap kandungan nutrisi suatu tanaman. Hal tersebut dikarenakan kandungan nutrisi tanaman paling banyak terdapat pada daun dibanding dengan batang, apabila rasio daun lebih besar dibandingkan dengan batang maka jumlah nutrisi pada tanaman semakin tinggi (Karim, et al., 1991). Kandungan nutrisi seperti kadar air, protein, serat kasar, lemak, dan abu tanaman sangat berperan terhadap produksi ternak, sehingga umur pemotongan tanaman harus diperhatikan agar pemanfaatan tanaman tersebut dapat dimaksimalkan. Tarigan et al., 2010 menyatakan bahwa umur pemotongan
Indigofera zollingeriana 60 hari menghasilkan kandungan protein kasar yang lebih tinggi tinggi jika dibandingkan dengan umur pemotongan 90 hari atau 30 hari. Hal ini berkaitan dengan fase pertumbuhan tanaman, yaitu fase vegetatif dan generatif.

Intensitas pemotongan adalah tinggi rendahnya pemotongan/renggutan. Intensitas pemotongan dimaksudkan sebagai tinggi pemotongan dari atas permukaan tanah (Kristyowantari, 1992). Frekuensi dan intensitas defoliasi mempengaruhi produksi dan mobilisasi $\mathrm{N}$ pada tanaman. Intensitas defoliasi meningkatkan penyerapan $\mathrm{N}$ yang dialokasikan untuk pertumbuhan daun yang diperoleh dari akar dan daun tua (Lestienne, et al., 2006). Intensitas pemotongan berpengaruh terhadap jumlah cabang dengan tendensi meningkatnya jumlah cabang dengan rendahnya tinggi pemotongan (Tarigan et al., 2010). Pada tanaman dengan intensitas pemotongan yang rendah ketersediaan cadangan energi lebih tinggi untuk mendukung perkembangan jumlah cabang. Pemotongan secara langsung akan menurunkan laju fotosintesis kemudian tanaman akan mendistribusikan karbohidrat (fotosintat) sebagai sumber energi ke jaringan lain seperti jaringan meristem pucuk atau akar, sehingga pertumbuhan akar serta percabangan 
tanaman meningkat, dan akan diikuti oleh produksi biomasa yang tinggi (Kertulis, 2001). Dengan pemangkasan, cadangan karbohidrat yang terdapat pada batang dan akar segera digunakan untuk menumbuhkan tunas-tunas baru, sehingga akan menghasilkan produksi biomasa tanaman lebih tinggi. Pada penelitian (Abdullah, 2014) semakin sering Indigofera zollingeriana diberi perlakuan pemotongan semakin bertambah juga produksi dari hijauan tersebut, dengan itu disimpulkan bahwa Tinggi pemangkasan (intensitas defoliasi) berpengaruh terhadap produksi hijauan. Sejalan dengan itu dalam penelitian (Volesky dan Anderson, 2007) menyebutkan bahwa intensitas pemotongan akan mempengaruhi produksi dari tanaman. Namun terhadap kualitas nutrisi tidak berpengaruh nyata walaupun terlihat adanya perbedaan pada setiap pemotongan dengan ketinggian yang berbeda. Tanaman leguminosa pohon, sangat memerlukan pemotongan baik frekuensi maupun intensitasnya selama musim kering, untuk mengurangi evapotranspirasi, merangsang perbanyakan produksi biomasa, serta meningkatkan kandungan mineral esensial dari tanaman tersebut (Miquelena et al. 2000).

\section{MATERI DAN METODE} PENELITIAN

\section{Waktu dan Tempat Penelitian}

Percobaan ini telah dilaksanakan pada bulan Desember 2019 sampai dengan Maret 2020 di kebun percobaan BPPTP di Desa Pandu, Kecamatan Wori, Manado Propinsi Sulawesi Utara. Secara geografis terletak pada $01^{0} 30^{\prime} \mathrm{LU}$, dan pada $124^{0}$ 54' BT, dengan tinggi tempat 67 meter dari atas permukaan laut (dpl).

\section{Materi Penelitian}

Materi yang digunakan pada penelitian ini meliputi bahan dan alat. Bahan yang digunakan antara lain: Indigofera zollingeriana berasal dari laboratorium Agrostologi Institut Pertanian Bogor. Alat yang digunakan antara lain: alat tulis, buku, kamera, polybag, alat timbang, gergaji, alat ukur, nampan, alas jemur, kantong plastik, kantong kertas, kertas label, plastik, dan gunting.

\section{Metode Rancangan Penelitian}

Rancangan yang digunakan adalah Rancangan Acak Lengkap (RAL) menurut petunjuk Stell and Torrie (1995) dengan 4 perlakuan intensitas pemotongan, masingmasing perlakuan diulang sebanyak 5 kali. Perlakunan intensitas pemotongan yaitu:
$\mathrm{I}_{1}: 75 \mathrm{~cm}$
$\mathrm{I}_{2}: 100 \mathrm{~cm}$
$\mathrm{I}_{3}: 125 \mathrm{~cm}$
$\mathrm{I}_{4}: 150 \mathrm{~cm}$ 


\section{Variabel yang diukur}

1. Produksi Bahan Segar Daun

Produksi bahan segar daun dihitung berdasarkan total produksi/panen (g/tanaman)

\section{Produksi Bahan Segar Batang}

Produksi bahan segar batang dihitung berdasarkan total produksi/panen (g/tanaman)

\section{Produksi Berat Kering Daun}

Produksi bahan kering daun dihitung berdasarkan produksi berat segar dikali dengan kandungan bahan kering.

4. Produksi Berat Kering Batang

Produksi bahan kering batang dihitung berdasarkan produksi berat segar dikali dengan kandungan bahan kering.

\section{Rasio Daun Dan Batang}

Rasio daun dan batang di hitung berdasarkan perbandingan jumlah berat daun kering dan batang kering.

\section{Prosedur Penelitian}

Tahapan perlakuan penelitian ini adalah sebagai berikut:

\section{Pengolahan tanah}

Sebelum pengolahan tanah, tedahulu dilakukan pembersihan lahan, setelah bersih dilakukan pembajakan dengan traktor untuk memecahkan lapisan tanah menjadi bongkahan-bongkahan dan membalikkan lapisan tanah kemudian dibiarkan beberapa hari. Selanjutnya tanah digemburkan dengan menggunakan traktor/cangkul sehingga menjadi struktur yang remah, sekaligus membersihkan sisasisa perakaran gulma.

2. Pembuatan demplot

Penentuan petak percobaan dalam demplot dilakukan secara acak disesuaikan dengan kondisi lahan. Petak percobaan terdiri dari 20 petak masing-masing berukuran $3 \mathrm{~m}$ x $4 \mathrm{~m}$ dalam 1 petakan ada 12 tanaman, dengan jarak antar petak $1 \mathrm{~m}$.

3. Penyiapan bibit

Bibit Indigofera zollingeriana diperoleh dari laboratorium Agrostologi fakultas peternakan IPB. Penanaman Indigofera zollingeriana dimulai dengan persemaian di tempat semai (seeding tray/baki) yang berisi tanah dan kompos dengan perbandingan $1: 1$, benih langsung ditabur secara merata ke permukaan media tanam pada baki. Penyiraman dilakukan hati-hati agar kecambah tidak rusak, tidak tergenang. Hari ke 7-10 dipindahkan ke polibag ukuran $0,5 \mathrm{~kg}$ masing diisi satu tanam Indigofera zollingeriana sampai umur 8 minggu. Tanaman kemudian dipindahkan kepetakan percobaan yang telah disiapkan sesuai dengan jarak tanam.

\section{Pemanenan}

Setelah 3 bulan ditanam di lahan, dilakukan pemangkasan indigofera sesuai dengan perlakuan intensitas pemotongan yaitu $75 \mathrm{~cm}, 100 \mathrm{~cm}, 125 \mathrm{~cm}$, dan $150 \mathrm{~cm}$ dari atas permukaan tanah. Panen dilakukan dengan memotong bagian tajuk 
Tabel 1. Berat Segar Daun dan Batang (g/tanaman)

\begin{tabular}{lcccc}
\hline \multirow{2}{*}{ Variabel } & \multicolumn{4}{c}{ Perlakuan } \\
\cline { 2 - 5 } & $\mathrm{I}_{1}$ & $\mathrm{I}_{2}$ & $\mathrm{I}_{3}$ & $\mathrm{I}_{4}$ \\
\hline Berat daun segar & $1089,80^{\mathrm{a}}$ & $1077,80^{\mathrm{a}}$ & $782,40^{\mathrm{b}}$ & $707,20^{\mathrm{b}}$ \\
Berat batang segar & $1241,30^{\mathrm{a}}$ & $951,60^{\mathrm{b}}$ & $676,40^{\mathrm{bc}}$ & $633,20^{\mathrm{c}}$ \\
Berat daun kering & $516,10^{\mathrm{a}}$ & $469,60^{\mathrm{ab}}$ & $394,20^{\mathrm{ab}}$ & $341,90^{\mathrm{b}}$ \\
Berat batang kering & $559,80^{\mathrm{a}}$ & $510,20^{\mathrm{a}}$ & $266,50^{\mathrm{b}}$ & $267,60^{\mathrm{b}}$ \\
Rasio daun/batang & $0,922^{\mathrm{c}}$ & $0,932^{\mathrm{c}}$ & $1,491^{\mathrm{a}}$ & $1,285 \mathrm{~b}$ \\
\hline
\end{tabular}

Keterangan : Superskrip yang berbeda pada baris yang sama menunjukkan berbeda sangat nyata $(\mathrm{P}<0,01)$

tanaman, kemudian daun dan batang dipisahkan. Sampel Indigofera zollingeriana dikeringkan di bawah sinar matahari.

\section{HASIL DAN PEMBAHASAN}

Produktivitas indigofera dapat dinyatakan melalui produksi berat segar daun dan batang, produksi berat kering daun dan batang, serta rasio daun/batang. Pengaruh intensitas pemotongan Indigofera zollingeriana terhadap berat daun segar, berat batang segar, berat daun kering, berat batang kering dan rasio daun/batang dapat dilihat pada Tabel 1.

\section{Pengaruh Perlakuan Terhadap Berat Segar dan Kering Daun}

Pengaruh intensitas pemotongan terhadap berat segar dan berat kering daun dapat dilihat pada tabel 1. Berat segar daun berkisar $\quad 707,20 \quad$ sampai 1089,80 gram/tanaman. Hal ini terjadi karena pada pemotongan $150 \mathrm{~cm}$ bagian cakupan tanaman yang terpotong relatif lebih sedikit jika dibandingkan dengan pemotongan yang lain karena semakin tinggi pemotongan berarti bagian tanaman yang terpotong juga akan semakin sedikit. Pada hasil penelitian (Tarigan et al., 2013) Rataan produksi segar Indigofera sp yang dipanen pada 50, 100, dan $150 \mathrm{~cm}$ secara berturut-turut adalah 12,27: 16,01 dan 18,84 ton/ha/tahun. Berat kering daun berkisar antara 341,90 sampai 516,10 gram/tanaman. Hal ini terjadi karena hijauan yang diberi perlakuan intensitas pemotongan $150 \mathrm{~cm}$ bagian cakupan tanaman (daun/batang) yang diperoleh lebih sedikit dibandingkan dengan intensitas pemotongan $125 \mathrm{~cm}$ dan $75 \mathrm{~cm}$. Mengambil referensi berat kering daun dari penelitian (Anis et al., 2019) Berat kering daun berturut-turut 13.6, 16.59, dan 15.75 dengan tinggi tanaman tertinggi pada jarak tanam $1,0 \mathrm{~m} \mathrm{x} \mathrm{1,0} \mathrm{m} \mathrm{yaitu} 86,57 \mathrm{~cm}$ dan menghasilkan berat kering daun 16.59. 
Hasil analisis keragaman menunjukkan bahwa intensitas pemotongan memberikan pengaruh yang berbeda sangat nyata $(\mathrm{P}<0,01)$ terhadap berat segar dan berat kering daun. Uji Beda Nyata Jujur menunjukkan bahwa intenstas pemotongan $150 \mathrm{~cm}$ menghasilkan berat segar dan berat kering daun yang sangat nyata lebih rendah dari intensitas pemotongan 75 dan $100 \mathrm{~cm}$. Hal ini disebabkan karena semakin tinggi cakupan bagian hijauan yang di panen maka semakin sedikit juga jumlah bagian hijauan yang diperoleh, berakibat pada rendahnya berat segar dan kering daun.

\section{Pengaruh Perlakuan Terhadap Berat Segar dan Kering Batang}

Pengaruh intensitas pemotongan terhadap berat segar dan berat kering batang dapat dilihat pada Tabel 1. Berat segar batang berkisar 633,20 sampai 1241,30 gram/tanaman. Pada hasil penelitian (Anis et al., 2019) yang menggunakan beberapa perlakuan jarak tanam mendapatkan Diameter batang berturut-turut $0.93,1.18,1.04$ dan Jumlah cabang berturut turut $8.27,11.60,11.00$. dengan tinggi tanaman tertinggi pada jarak tanam 1,0 m x 1,0 m yaitu 86,57 cm. Semakin banyak jumlah cabang, semakin tinggi titik pertumbuhan untuk pengembangan daun dan akan terkait dengan ketersediaan cadangan energi (karbohidrat) yang menopang pertumbuhan tanaman hijauan (Ngo dan Hao 1993; Anis et al 2016). Berat kering batang berkisar 267,60 sampai 559,80 gram/tanaman. Pada hasil penelitian (Anis et al., 2019) yang menggunakan beberapa perlakuan jarak tanam mendapatkan berat kering batang berturut-turut 7.54, 9.31 dan 9.14 dengan tinggi tanaman tertinggi pada jarak tanam $1,0 \mathrm{~m} \mathrm{x} 1,0 \mathrm{~m}$ yaitu $86,57 \mathrm{~cm}$. Dapat disimpulkan dalam hal intensitas bahwa semakin rendah tinggi pemotongan hijauan berarti semakin banyak juga cakupan hijauan yang dipotong/dipanen sehingga hijauan yang diberi perlakuan intensitas pemotongan rendah memiliki berat kering yang lebih berat dibandingkan hijauan yang diberi perlakuan intensitas tinggi. Hasil analisis keragaman menunjukkan bahwa intensitas pemotongan memberikan pengaruh yang berbeda sangat nyata $(\mathrm{P}<0,01)$ terhadap berat segar dan berat kering daun. Uji Beda Nyata Jujur menunjukkan bahwa intensitas pemotongan $150 \mathrm{~cm}$ menghasilkan berat segar dan berat kering batang yang sangat nyata lebih rendah dari intensitas pemotongan 75 dan $100 \mathrm{~cm}$. Hal ini disebabkan karena pemotongan yang lebih rendah berarti jumlah hijauan yang di panen lebih banyak sebaliknya pada pemotongan yang lebih tinggi jumlah hijauan yang di panen akan lebih sedikit, berakibat pada rendahnya berat segar dan kering batang pada intensitas pemotongan $150 \mathrm{~cm}$. 
Sedangkan antara intensitas pemotongan $125 \mathrm{~cm}$ dan $150 \mathrm{~cm}$ tidak terdapat perbedaan berat segar dan kering batang yang signifikan karena beberapa faktor internal dan eksternal yang mempengaruhi, contoh faktor internal yaitu terdapat perbedaan tinggi dan ukuran antar hijauan yang di beri perlakuan intensitas pemotongan sedangkan faktor eksternalnya bisa beragam diantarannya terdapat perbedaan intensitas cahaya matahari antar hijauan karena adanya naungan pohon kelapa dan faktor lainnya terdapat pengairan yang kurang merata yang berakibat terjadinya perbedaan kemampuan tumbuh antar hijauan itu sendiri.

\section{Pengaruh Perlakuan Terhadap Rasio Daun/Batang}

Pengaruh interval pemotongan terhadap rasio daun/batang dapat dilihat pada Tabel 1. Rasio daun/batang pada intensitas pemotongan $75 \mathrm{~cm}, 100 \mathrm{~cm}, 125$ $\mathrm{cm}$ dan $150 \mathrm{~cm}$ berturut-turut 0,922, 0,932, 1,491 dan 1,285. Dalam Penelitian (Tarigan et al., 2013) rataan rasio daun/batang Indigofera sp pada intensitas pemotongan $50,100,150 \mathrm{~cm}$ secara berturut-turut 1,72; 1,71 dan 1,63. Rasio daun/batang perlakuan tinggi pemotongan $50 \mathrm{~cm}(1,72)$ lebih tinggi dibandingkan dengan rasio daun/batang perlakuan tinggi pemotongan yang lainya. Hasil ini disebabkkan karena salah satu faktor yang mempengaruhi yaitu pada penelitian (Taringan et al., 2013) menerapkan beberapa jenis perlakuan jarak tanam. Pada tanaman dengan tinggi pemotongan yang rendah ketersediaan cadangan energi lebih tinggi untuk mendukung perkembangan jumlah cabang. Penurunan jumlah cabang sebesar 50\% akibat meningkatnya tinggi pemotongan terkait dengan ketersediaan cadangan energi (karbohidrat) setelah pemotongan untuk menopang pertumbuhan kembali (regrowth) (Anis, 1992). Hasil analisis keragaman menunjukkan bahwa intensitas pemotongan memberikan pengaruh yang berbeda sangat nyata $(\mathrm{P}<0,01)$ terhadap rasio daun/batang. Uji Beda Nyata Jujur menunjukkan bahwa intensitas pemotongan $125 \mathrm{~cm}$ menghasilkan daun/batang yang sangat nyata lebih tinggi dari interval pemotongan $75 \mathrm{~cm}$ dan 100 cm. Hal ini disebabkan karena beberapa faktor eksternal tanaman seperti, Intensitas cahaya matahari untuk keperluan fotosintesis yang kurang karena adanya perbedaan intensitas naungan dibawah pohon kelapa. Tarigan et al., 2013 menyatakan Peranan cahaya bagi tanaman terlihat jelas dalam proses fotosintesis, yang ditangkap oleh klorofil untuk menghasilkan bahan baku untuk pertumbuhan antara lain pembentukan bunga, daun, dan perkecambahan. (Telleng, 2017) menyatakan rasio batang/daun pada leguminosa pohon sangat penting karena 
organ metabolisme utama untuk proses fotosintesis adalah daun, semakin tinggi jumlah daun maka kualitas hijauan leguminosa tersebut semakin baik, Sejalan dengan itu, Herdiawan dan Krisna (2014) menyatakan bahwa daun merupakan bagian jaringan tanaman yang memiliki kandungan nutrisi paling tinggi dibandingkan dengan batang/ranting. Bagian tanaman yang disukai oleh ternak dan memiliki kualitas nutrisi yang lebih tinggi adalah fraksi daun (Shehu et al., 2001). Karena itu, rasio daun / batang menjadi penting. Faktor lain yang mempengaruhi yaitu pengairan yang kurang merata karena kondisi lahan dan juga kondisi hijauan itu sendiri seperti perbedaan tinggi, jumlah cabang dan jumlah daun hijauan tersebut.

\section{KESIMPULAN}

\section{Produktivitas}

Indigofera

zollingeriana tertinggi yaitu pada intensitas pemotongan $125 \mathrm{~cm}$.

\section{DAFTAR PUSTAKA}

Abdullah, L. dan Suharlina. 2010. Herbage yield and quality of two vegetative parts of Indigofera at different times of first regrowth defoliation. Jurnal Media Peternakan 33(1): 44-49.

Abdullah, L. 2014. Prospektif agronomi dan ekofisiologi Indigofera zollingeriana sebagai tanaman penghasil hijauan pakan berkualitas tinggi. Pastura 3(2): $79-83$.

Akbarillah, T. dan D. Kaharuddin. 2002. Kajian daun tepung Indigofera sebagai suplemen pakan produksi dan kualitas telur. Dalam: Laporan penelitian. Bengkulu (Indonesia): Lembaga Penelitian Universitas Bengkulu.

Anis, S. D, 1992. Pengaruh kepadatan dan interval pemotongan Gliricidia sepium terhadap produksi dan mutu hijauan di lahan pertanaman kelapa. Tesis. Sekolah Pasca Sarjana, KPK Institut Pertanian Bogor-Universitas Sam Ratulangi.

Anis, S. D., D. A. Kaligis, B. Tulung, dan Aryano. 2016. Leaf quality and yiels of Gliricidia sepium(Jacq) steud under different population density and cutting interval in coconut plantation. J. of the Indonesian Tropical Animal Agriculture 41(2): 91-97.

Anis, S. D., Ch. L. Kaunang, M. M. Telleng, W. B. Kaunang, C. J. Sumolang, dan U. Paputungan. 2019. Preliminary evaluation on morphological response of Indigofera zollingeriana tree legume under different cropping patterns grown at 12 weeks after planting underneath mature coconuts., Livestock Research for Rural Development 31 (9).

Hassen, A., N. F. G. Rethman, W. A. Van Niekerk, T. J. Tjele. 2007. Influence of aeason/year and species on chemical composition and in vitro digestibility of five Indigofera sp. Accessions. J. Anim Feed Sci Teechnol. 136:312-322. 
Herdiawan, I. dan R. Krisna. 2014. Produktivitas dan pemanfaatan tanaman leguminosa pohon Indigofera zollingeriana pada lahan kering. Jurnal Wartazoa 24(2): 7582.

Karim, A. B., E. R. Savill, P. S. Sierra Leone, 1991. Effect of CuttingInterval on Dry Matter Yieldof Leucaena leucocephala (Lam) De Wit. J Agrofor Syst. 16:129-137.

Kertulis, G.M. 2001. Effects of nitrogen and cutting management on root growth and productivity of a kentucky bluegrass (Poa pratensis L.) and white clover (Trifolium repens L.) pasture. Thesis. College of Agriculture, Forestry and Consumer Sciences at West Virginia University.

Kristyowantari, R. 1992. Pengaruh interval dan tinggi pemotongan terhadap produksi dan beberapa aspek kualitas rumput raja. Skripsi. Fakultas

Peternakan. Institut Pertanian Bogor, Bogor.

Lestienne, F., B. Thornton, F. Gastal, 2006. Impact of defoliation intensity and frequency on $\mathrm{N}$ uptake and mobilization in Lolium perenne. Journal of Experimental Botany 57 (4): 997-1006.

Miquelena, E., O. Ferrer, M. Medina, 2000. Frequency and height of defoliation on the nitrogenous fractions of Acacia mangium Willd. Cuban Journal. Agric. Sci. 34: 65-71.

Ngo, V. M. dan N.G. Hao. 1993. Effect of plant spacing on the growth and yield of four legume trees in the grey soil of eastern South Vietnam. Livestock
Research for Rural Development 5 (1)

Shehu, Y., W.S. Alhassan, U. R. Pal, C.J.C. Phillips, 2001. Yield and chemical composition response of Lablab purpureus to nitrogen, phosphorus and potassium fertilizers. Trop Grassl. 35:180-185.

Steel, R. C. dan Torrie J. H. 1995. Prinsip dan prosedur statistika. Gramedia Pustaka Utama. Jakarta.

Tarigan, A., L. Abdullah, S. P. Ginting, I. G. Permana, 2010. Produksi dan komposisi nutrisi serta kecernaan in vitro Indigofera sp pada interval dan tinggi pemotongan berbeda. JITV. 15: 188-195.

Taringan, A., J. Sirait, S.P. Ginting. 2013. Produksi dan komposisi nutrisi Indigofera Sp. pada intensitas pemotongan dan jarak tanam yang berbeda di dataran tinggi dengan curah hujan sedang. Loka Penelitian Kambing Potong, Sei Putih, Seminar Nasional Teknologi Peternakan dan Veteriner 2013.

Telleng, M. M., K. G. Wiryawan, P. D. M. H. Karti, I. G. Permana, L. Abdullah, 2016. Forage production and nutrient composition of different sorghum varieties cultivated with Indigofera in intercropping system. Jurnal Media Peternakan. 39 (3): 203-209.

Telleng, M. M. 2017. Penyediaan pakan berkualitas berbasis sorgum (Sorgum bicolor) dan Indigofera (Indigofera zollingeriana) dengan pola tanam tumpang sari. Disertasi. Bogor: Sekolah Pascasarjana, Institut Pertanian Bogor.

Tillman, A. D., H. Hartadi, S. Reksohadiprojo, S. Prawirokusumo, S. Lebdosoekojo, 1998. Ilmu makanan ternak dasar. Edisi 
Zootec Vol. 40 No. 2 : 665 - 675 (Juli 2020)

Keenam. Gadjah Mada University Press. Yogyakarta.

Volesky, J. D. dan B. E. Anderson. 2007. Defoliation effects on production and nutritive value of four irrigated cool-season perennial grasses. Agron. J. 99:494-500. 